\title{
Radiotherapy and Rosai-Dorfman disease
}

\author{
Radioterapia e doença de Rosai-Dorfman \\ Antonio Cássio Assis Pellizzon ${ }^{1}$
}

\begin{abstract}
Rosai-Dorfman disease (RDD) also known as histiocytosis with lymphadenopathy is an uncommon, often self-limiting benign, non-Langerhans-cell histiocytic proliferative disorder. It usually affects young adults and children, with no predilection by sex. More than $80 \%$ of patients present with painless cervical lymphadenopathy, with or without fever. Other presentation sites include upper aero-digestive tract, orbits and the paranasal sinuses. Extra nodal involvement occurs in up to $40 \%$ of cases and common sites of involvement include the skin, upper and lower respiratory tract, soft tissue, bones, kidney, liver, orbit and central nervous system. Treatment is not necessary in most instances, but some patients, when symptomatic, may require medical intervention. There is no established guideline for the management of this condition and various therapeutic modalities are used, including surgery, radiotherapy and or chemotherapy.
\end{abstract}

Keywords: Histiocytosis, sinus; Proliferative disorder; Radiotherapy; Surgery

\begin{abstract}
RESUMO
A doença de Rosai-Dorfman, também conhecida como histiocitose com adenopatia, é uma desordem linfo-proliferativa de histiócitos não Langerhans, rara e geralmente auto limitada. Ela usualmente afeta adultos jovens e crianças, sem predileção por sexo, com ou sem a presença de febre associada. Outros sítios de acometimento incluem o trato aéreo e digestivo altos, orbitas e seios paranasais. O envolvimento extra-nodal pode ocorrer em até $40 \%$ e os sítios comumente acometidos são a pele, trato aéreo alto e baixo, partes moles, ossos, rim, fígado, orbita e sistema nervoso central. $\mathrm{O}$ tratamento não é necessário na maioria dos casos, porem, em alguns pacientes pode ser necessário algum tipo de intervenção. Não existe um protocolo de tratamento estabelecido para essa doença, e são varias as opções terapêuticas que podem ser empregadas, dentre elas cirurgia, radioterapia e quimioterapia.
\end{abstract}

Keywords: Histiocitose sinusal; Transtorno histiocítico proliferativo; Radioterapia; Cirurgia

1. AC Camargo Cancer Center, São Paulo, SP, Brazil.

Conflicts of interest: no.

Corresponding author: Antonio Cássio Assis Pellizzon

R. Prof Antônio Prudente, 211. Liberdade, São Paulo, SP, Brazil. Zip code: 01509-020. Phone: +55-11-21895101.

E-mail - acapellizzon@accamargo.org.br

Received on: June 23, 2017 | Accepted on: September 20, 2017

DOI: 10.26790/BJO20171346A99 


\section{INTRODUCTION}

Rosai-Dorfman disease (RDD) is an uncommon, often self-limiting benign, non-Langerhans-cell histiocytic proliferative disorder, first described by Rosai and Dorfman in 1969 as sinus histiocytosis with lymphadenopathy. ${ }^{(1,2)}$ This rare benign histiocyte disorder can have nodal and extranodal manifestations, the last one occurring occurring in up to $40 \%$ of patients. ${ }^{(3,4)}$ Extra nodal involvement occurs in up to $40 \%$ of cases and common sites of involvement include the skin, upper and lower respiratory tract, soft tissue, bones, kidney, liver, orbit and central nervous system. Treatment is not necessary in most instances,(5) but some patients, when symptomatic, may require medical intervention. In the absence of established guidelines for the management of this condition, various therapeutic modalities are used, including surgery, radiotherapy and or chemotherapy for disease manifestations. ${ }^{(3)}$

\section{PRESENTATION}

Rosai-Dorfman disease is a benign disorder that usually affects young adults and children, with no predilection by sex. More than $80 \%$ of patients present with painless cervical lymphadenopathy, with or without fever. ${ }^{(1,2)}$ Other presentation sites include upper aero-digestive tract, orbits and the paranasal sinuses.

Extra nodal involvement occurs in fewer than $40 \%$ of cases, being more common in elderly patients. In this situation common sites of involvement include the skin, upper airway and soft tissue..$^{(6,7)}$

Bones can also be affected, but are the less frequent presentation. ${ }^{(1,3)}$ Figures 1 and 2 show a CT scan of a lesion presenting in the left femur with important infiltration of periosteal reaction and muscular and soft tissue infiltration.

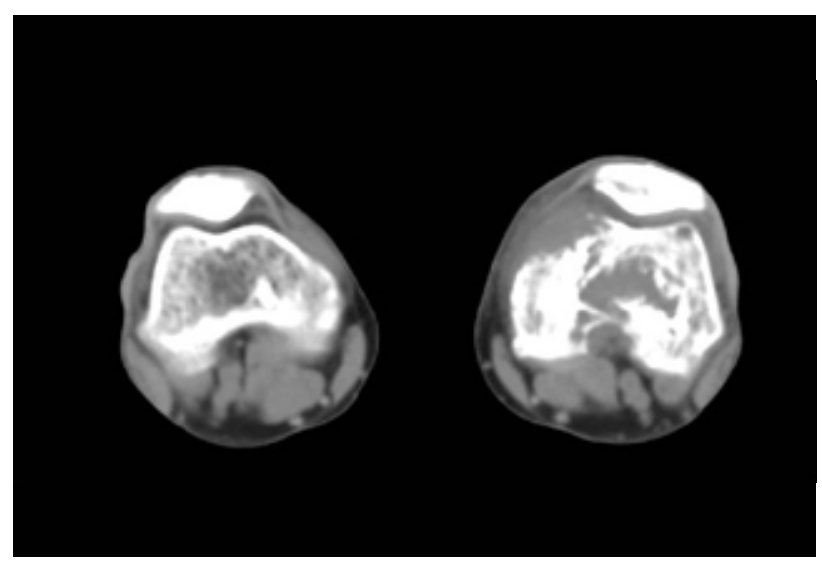

Figure 1. Axial CT image of a lesion in left distal femur

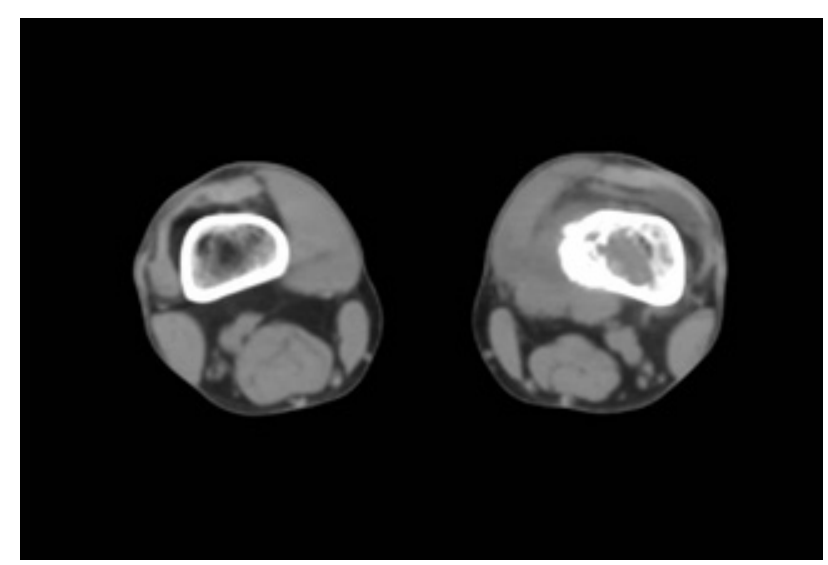

Figure 2. Axial CT image of a lesion in the diaphysis of the left femur

The lesions presenting in the skin in general have a xanthomatous appearance, papular or nodular, with no more than $4 \mathrm{~cm}$ in diameter. ${ }^{(8)}$ However, lesions with size of up to $12 \mathrm{~cm}$ have been reported.(9)

Rosai-Dorfman disease also can occur in a variety of other sites, including the genitourinary system, lower respiratory tract, oral cavity, and soft tissues. (10) Involvement of kidney, lower respiratory tract, or liver was found to be a poor prognostic sign, and patients with associated immunologic disease often fared poorly. ${ }^{(6)}$

Approximately $40 \%$ of cases present with extranodal disease and $10 \%$ have orbital involvement with only one third of these having bilateral disease. Orbital involvement often presents as painless proptosis. 
Patients can present with lesions in the skin of the lids or other soft tissues of the orbit. Difficulties with extra ocular movements and lid closure can follow with more progressive disease. Corneal ulceration, decreased visual acuity and blindness can occur eventually. ${ }^{(11)}$ Involvement of the CNS remains, however, rare with 32 reported cases in the literature.
All patients underwent surgical treatment and the primary pre-operative diagnosis was meningioma in $93 \%$ of the cases. ${ }^{(12)}$

In general, prognosis has been found to correlate both with the number of nodal groups and with the number of extra nodal systems involved by RDD. ${ }^{(6)}$

\section{HISTOLOGY}

Rosai and Dorfman first described 4 cases of the clinicopathologic entity known as sinus histiocytosis with massive lymphadenopathy in 1969. ${ }^{(1,2)}$

Histological studies include RDD cells in the macrophage/histiocyte family, but their exact origin is still unknown. Scattering, clusters or sheets of large polygonal histiocytes intermingled with a florid, mixed inflammatory infiltrate. Patch and bandlike infiltrate of numerous mature plasma cells around glands and vessels is a constant finding. ${ }^{(9)}$ The presence of emperipolesis of leukocytes, which can be highlighted by S-100 protein stain, and concurrent histiocytosis on pathology examination is mandatory, histiocytes also have abundant cytoplasm. ${ }^{(1)}$
A report published by Eisen et al. showed that RDD cells can also express "pan-macrophage" antigens such as EBM11, HAM 56, and Leu-M3, antigens functionally associated with phagocytosis (Fc receptor for IgG, complement receptor 3), and lysosomal activity (lysozyme, alpha 1-antichymotrypsin, and alpha 1-antitrypsyn), antigens associated with early inflammation (Mac-387, 27E10), antigens commonly found on monocytes, but not tissue macrophages (OKM5, Leu-M1), and "activation" antigens (Ki-1 and receptors for transferrin and interleukin 2).

These data suggest that SHML cells are true functionally activated macrophages that may be recently derived from circulating monocytes. ${ }^{(13)}$

\section{TREATMENT}

Currently, there are no clear guidelines and no ideal treatment protocol exists for the management of RDD. The disease may have a benign course without therapy, but surgery may be required to relieve obstructive symptoms.

Initial management usually consists of either incisional or excisional biopsy, followed by observation in most cases. The surgical management is usually reserved for recurrent lesions causing functional disability or obstruction of critical structures.

About one third of patients can achieve complete or partial response to the use of corticosteroids alone.

In more symptomatic and advanced disease various chemotherapeutic regimens have been tried so far. The combinations of vinca alkaloids, alkylating antineoplastic agents, and or corticosteroids appear to be the most effectives. ${ }^{(5)}$
Treatments with acyclovir or interferon alpha have also being documented in the literature with anecdotal responses. ${ }^{(14,15)}$

There is a paucity of information in the literature describing techniques and doses of radiation therapy (RT), despite its relative success, and probably due to its relationship with potential malignant transformation. Advances in the planning and delivery of RT in its various modalities, warrant the reporting of recent RT treatments.

The largest series reporting the use of RT in the treatment of RDD was published by Komp et al. ${ }^{(5)} \mathrm{RT}$ treatments were documented in 34 out of 418 patients with RDD. Unfortunately, RT dose was reported in only 18 patients, with no clear relationship between dose and response. There were 5 patients who received doses between 30 Gy and 49 Gy, with 1 patient presenting complete response and another partial 
response, and 3 had no response. Doses above 50 Gy were used in 2 patients, achieving partial response in 1 and no response in the second. The remaining 11 patients received doses of less than $30 \mathrm{~Gy}$, with 3 partial and 8 absence of response.

Modern RT techniques, such as intensity-modulated radiation therapy (IMRT), have been introduced to minimize the risk of treatment-related toxicity, but they have not been formally evaluated in this situation.

RT can also be prescribed as primary or postoperative treatment, and in some instances to treat recurrent disease.

As the etiology of the heterogenic response rates of these tumors is still unclear, we conclude that due the paucity of data and published papers mainl based on case reports or small cohorts, a RT dose- response relationship cannot currently be securely suggested. Other factors that affect the definition of this relationship are poor reporting of treatment plans and dosimetry, variation on schedule and dose fractionation of radiotherapy, besides the rarity of the disease, patient inconvenience, in general daily treatments over 2 weeks, expense and somewhat obscure mechanisms of action.

In conclusion, RDD is an uncommon, often self-limiting benign with no clear treatment protocol. In most instances RDD does not require treatment, but some patients, when symptomatic, may require medical intervention that can include: corticosteroids alone in most situations. In more symptomatic and advanced disease chemotherapy or radiotherapy are reasonable options and the surgical management is, generally, reserved for recurrent disease.

\section{REFERENCES}

1. Rosai J, Dorfman RF. Sinus histiocytosis with massive lymphadenopathy. A newly recognized benign clinicopathological entity. Arch Pathol. 1969;87(1):63-70.

2. Rosai J, Dorfman RF. Sinus histiocytosis with massive lymphadenopathy: a pseudolymphomatous benign disorder. Analysis of 34 cases. Cancer. 1972;30(5):1174-88.

3. Annessi G, Giannetti A. Purely cutaneous Rosai--Dorfman disease. Br J Dermatol. 1996;134(4):749-53.

4. Rodriguez-Galindo C1, Helton KJ, Sánchez ND, Rieman M, Jeng M, Wang W. Extranodal Rosai-Dorfman disease in children. J Pediatr Hematol Oncol. 2004;26(1):19-24.

5. Komp DM. The treatment of sinus histiocytosis with massive lymphadenopathy (Rosai-Dorfman disease). Semin Diagn Pathol. 1990;7(1):83-6.

6. Foucar E, Rosai J, Dorfman R. Sinus histiocytosis with massive lymphadenopathy (Rosai-Dorfman disease), review of the entity. Semin Diagn Pathol 1990;7(1):19-73.

7. Hsiao CH, Tsai TF, Yang TH, Liu CM. Clinicopathologic characteristics of Rosai-Dorfman disease in a medical center in northern taiwan. J Formos Med Assoc. 2006;105(9):701-7.

8. Thawerani H, Sanchez RL, Rosai J, Dorfman RF. The cutaneous manifestations of sinus histiocytosis with massive lymphadenopathy. Arch Dermatol. 1978;114(2):191-7.

9. Kong YY, Kong JC, Shi DR, Lu HF, Zhu XZ, Wang J, Chen ZW.
Cutaneous rosai-dorfman disease: a clinical and histopathologic study of 25 cases in China. Am J Surg Pathol. 2007;31(3):341-50.

10. Young PM, Kransdorf MJ, Temple HT, Mousavi F, Robinson PG. Rosai-Dorfman disease presenting as multiple soft tissue masses. Skeletal Radiol. 2005;34(10):665-9.

11. Childs HA 3rd, Kim RY. Radiation response of Rosai-Dorfman disease presenting with involvement of the orbits. Am J Clin Oncol. 1999;22(5):526-8.

12. Petzold A, Thom M, Powell M, Plant GT. Relapsing intracranial Rosai-Dorfman disease. J Neurol Neurosurg Psychiatry. 2001;71(4):538-41.

13. Eisen RN, Buckley PJ, Rosai J. Immunophenotypic characterization of sinus histiocytosis with massive lymphadenopathy (Rosai-Dorfman disease). Semin Diagn Pathol. 1990;7(1):74-82.

14. Palomera L, Domingo JM, Olave T, Romero S, Gutierrez M. Sinus histiocytosis with massive lymphadenopathy: : complete response to low-dose interferon-alpha [letter]. J Clin Oncol. 1997;15(5):2176.

15. Baildam EM, Ewing Cl, D'Souza SW, Stevens RF. Sinus histiocytosis with massive lymphadenopathy (Rosai-Dorfman disease): response to acyclovir. J R Soc Med. 1992; 85(3):179-80. 